\title{
Avoiding autocannibalism
}

\section{Consider growth hormone and insulin-like growth factor 1}

Trauma, sepsis, and surgery increase the catabolic rate. If hypercatabolism is prolonged the resultant muscle wasting and impaired immune response delay recovery. ${ }^{1}$ The term autocannibalism has been used to describe this self destructive response to illness, ${ }^{2}$ and a malnourished state, due to increased catabolism, remains a common problem on many hospital wards.

In the 1930s Cuthbertson showed that even relatively minor trauma, such as a fractured tibia, was associated with a greatly increased catabolic rate and negative nitrogen balance (indicating net muscle loss). ${ }^{3}$ The breakdown of protein after trauma may have short term advantages-for example, providing amino acids for wound healing and for synthesising acute phase proteins in the liver. Critically ill patients remain in negative nitrogen balance for long periods despite enteral or parenteral nutrition. ${ }^{4}$ Although parenteral nutrition supports protein synthesis, its capacity to do so falls short of the demands of catabolism.

Other ways of promoting anabolism and preventing catabolism have been proposed. Insulin improves nitrogen balance in patients with trauma, but this effect is short lived..$^{56}$ Growth hormone, with its promotion of lipolysis, muscle synthesis, and the retention of nitrogen, is a logical choice for improving the nutritional state of the critically ill. The recent production of recombinant human growth hormone and its associated peptide insulin-like growth factor 1 has allowed further investigation of these compounds' anabolic potential.

Growth hormone has direct actions (lipolysis and insulin antagonism) and direct anabolic actions, which are mediated by insulin-like growth factor 1 . Fasting normal subjects and critically ill patients become relatively insensitive to growth hormone, with increased basal concentrations of the hormone associated with low concentrations of insulin-like growth factor $1 .{ }^{78}$ These observations suggest that the metabolic actions of growth hormone undergo adaptive change during sickness and fasting. ${ }^{9}$ Consequently, the indirect anabolic actions of growth hormone are reduced while the raised basal growth hormone concentrations promote increased lipolysis and insulin antagonism. Such changes might benefit fasting sick patients by providing metabolic fuels but at the cost of switching off protein synthesis. However, in the context of modern intensive care, where nutritional support is available, this could be counterproductive, with adverse effects on wound healing, muscle strength, and recovery.

Recent studies with recombinant growth hormone have shown that supraphysiological doses promote positive nitrogen balance in many groups: patients with burns, ${ }^{10}$ postoperative patients, ${ }^{11}{ }^{12}$ the critically ill, ${ }^{13}$ those with chronic lung disease, ${ }^{14}$ those receiving parenteral nutrition, ${ }^{15}{ }^{16}$ and healthy volunteers treated with steroids. ${ }^{17}$ The daily dose of growth hormone used in these studies was $0 \cdot 12-0 \cdot 40 \mathrm{U} / \mathrm{kg}$ body weight, equivalent to two to five times that used to treat growth hormone deficiency. To date, few studies have examined whether treatment with growth hormone influences outcome. Exceptions are one study showing that treatment with growth hormone reduced the stay in hospital for severely burnt children from an average of 46 to 32 days $^{10}$ and another showing that growth hormone increased the hand grip strength of postoperative patients. ${ }^{12}$ Studies suggest that treatment with growth hormone promotes muscle synthesis, although it does not prevent muscle breakdown. ${ }^{10-13} 18$ Severity of illness correlates with catabolic rate and resistance to the anabolic effects of growth hormone. ${ }^{13}$

Catabolic states are associated with low concentrations of insulin-like growth factor 1 . In the studies quoted above the response to growth hormone was associated with a rise in the serum concentration of insulin-like growth factor 1 , which may therefore prove to be a potent anabolic agent. It shares some structural homology and biological activities with insulin. Insulin reduces net nitrogen excretion in patients with sepsis, and, although the effect is small, ${ }^{5}$ it may be mediated by reduced muscle breakdown rather than increased protein synthesis. ${ }^{19}$

Abundant receptors for insulin-like growth factor 1 are present in muscle,$^{20}$ (though not in the liver). Its metabolic effects differ from those of insulin. In particular, insulin-like growth factor 1 selectively enhances uptake of glucose by muscle and seems not to suppress the hepatic production of glucose. ${ }^{21}$ Most of the insulin-like growth factor 1 in plasma circulates bound to a large molecular weight complex (about $150 \mathrm{kDa}$ ). Intravenous administration of insulin-like growth factor 1 causes a brief rise in free hormone concentration sufficient to act at the insulin receptor causing hypoglycaemia, although giving the drug subcutaneously avoids this. ${ }^{22}$ Recent studies in animals suggest that insulin-like growth factor 1 treatment can ameliorate weight loss induced by starvation, ${ }^{23}$ increase weight gain after burns injury, ${ }^{24}$ and reduce protein degradation in the fasted state. ${ }^{21}$ Further studies are under way to establish whether insulin-like growth factor 1 can prevent muscle degradation in hypercatabolic states in man. 
Future work will have to define which groups of patients will benefit from anabolic treatment and at what cost. In severely burnt children treatment with growth hormone lasted 32 days $^{10}$; a similar course of treatment for an adult would cost about $£ 6000$. Critically ill patients and those who are hypercatabolic because of long term treatment with steroids, chronic liver and renal failure, or burns are the groups in whom anabolic treatment might have the greatest impact.

No serious complications of treatment with recombinant growth hormone have been reported so far, and, although such treatment consistently raises concentrations of insulin, ${ }^{101117}$ insulin resistance has not proved to be clinically important. Insulin-like growth factor 1 is a potent mitogen in vitro, and the possibility that it might potentiate the spread of cancer requires long term evaluation.

"Eating people is wrong," sang Michael Flanders and Donald Swann, and autocannibalism may also be bad for you. Treatment with growth hormone or insulin-like growth factor 1 holds out the prospect of preventing autocannibalism by improving the efficiency with which the body handles nutritional supplementation.

Senior Registrar in Endocrinology

RICHARD J M ROSS

Research Fellow in Neuroendocrinology,

JOHN P MIELL

Department of Medicine,

King's College School of Medicine and Dentistry,

London SE5 9PJ

CHARLES R BUCHANAN

Lecturer in Growth and Development,

Department of Growth and Development,

Institute of Child Health,

London WCIN 1EH

(Correspondence to Dr Ross.)
1 Ryan NT. Metabolic adaptions for energy production during trauma and sepsis. Surg Clin North Am 1976;56:1073-90.

2 Cerra FB, Siegel JH, Coleman B, Border JR, McMenanamy RR. Septic autocannibalism-a failure of exogenous nutritional support. Ann Surg 1980;192:570-80

3 Cuthbertson DP. Observations on the disturbance of metabolism produced by injury to the limbs. Qf Med 1931;2:233-46.

4 Douglas RG, Shaw JHF. Metabolic response to sepsis and trauma. Br $\mathcal{F}$ Surg 1989;76:115-22.

5 Woolfson AMJ, Heatley RV, Allison SP. Insulin to inhibit protein catabolism after injury. NEngl f Med 1979;300:14-7.

6 Macfie J, Yule AG, Hill GL. Effect of added insulin on bods composition of gastroenterologic patients receiving intravenous nutrition-a controlled clinical trial. Gastroenterology 1981;81:285-9.

7 Phillips LS, Unterman TG. Somatomedin activity in disorders of nutrition and metabolism. Clin Endocrinol Metab 1984;13:145-89.

8 Ross RJM, Miell JP, Freeman E, Jones J, Matthews D, Preece M, et al. Critically ill patients have high basal growth hormone concentrations with attenuated oscillatory activity associated with high basal growth hormone concentrations with attenuated oscillatory activity as

9 Ross RJM, Buchanan CR. Growth hormone secretion: its regulation and the influence of nutritional factors. Nutrition Research Reviews 1990;3:143-62.

10 Herndon DN, Barrow RE, Kunkel KR, Broemeling L, Rutan RL. Effects of recombinant human growth hormone on donor-site healing in severely burnt children. Ann Surg 1990;212:424-9. 11 Ward HC, Halliday D, Sim JW. Protein and energy metabolism with biosynthetic human growt hormone after gastrointestinal surgery. Ann Surg 1987;206:56-61.

12 Jiang ZM, He GZ, Zhang SY, Wang XR, Yang NF, Zhu Y, et al. Low-dose growth hormone and hypocaloric nutrition attenuate the protein-catabolic response after major operation. Ann Surg 1989;210:513-24.

13 Douglas RG, Humberstone DA, Haystead A, Shaw JHF. Metabolic effects of recombinant human growth hormone: isotopic studies in the postabsorptive state and during total parenteral nutrition. Br f Surg 1990;77:785-90.

14 Suchner U, Rothkopf MM, Stanislaus G, Elwyn DH, Kvetan V, Askanazi J. Growth hormone and pulmonary disease. Arch Intern Med 1990;150:1225-30.

15 Ziegler TR, Young LS, Manson JM, Wilmore DW. Metabolic effects of recombinant human growth hormone in patients receiving parenteral nutrition. Ann Surg 1988;208:6-16.

16 Ponting GA, Ward HC, Halliday D, Sim AJW Protein and energy metabolism with hiosynthetic human , Ward human growth hormone in patients on full intravenous nutritional support. Foumal of Parenterd

17 Horber FF Haymond MW. Human growth hormone prevents the protein catabolic side effects of prednisolone in humans. $\mathcal{F}$ Clin Invest 1990;86:265-72.

18 Manson JM, Smith RJ, Wilmore DW. Growth hormone stimulates protein synthesis during hypocaloric parenteral nutrition. Ann Surg 1988;208:136-42.

19 Gelfand R, Barrett EJ. Effect of physiologic hyperinsulinaemia on skeletal muscle protein synthesis and breakdown in man. $\mathcal{F}$ Clin Invest 1987;80:1-6.

20 Florini JR. Hormonal control of muscle growth. Muscle Nerve 1987;10:577-98.

21 Jacob R, Barrett E, Plewe G, Fagin KD, Sherwin RS. Acute effects of insulin-like growth factor I on glucose and amino acid metabolism in the awake fasted rat. $\mathcal{F}$ Clin Invest 1989;83:1717-23.

22 Froesch ER, Guler H, Schmid C, Binz. K, Zapf J. Therapeutic potential of insulin-like growth factor I. Trends in Endocrinology and Metabolism 1990;1:254-60.

23 O'Sultivan U, Gluckman PD, Breier BH, Woodall S, Siddiqui RA, McCutcheon SN. Insulin-like growth factor 1 (IGF 1) in mice reduces weight loss during starvation. Endocrinolog 1989;125:2793-4.

24 Strock LL, Singh H, Abdullah A, Miller JA, Herndon DN. The effect of insulin-like growth factor 1 on postburn hypermetabolism. Surgery 1990;108:161-4.

\section{Patient's charter}

\section{New rights issue}

England (p 1153), ${ }^{12}$ Scotland, ${ }^{34}$ and Wales ${ }^{5}$ now all have their own patient's charters. Should this new initiative be welcomed, and will it make any difference? The answer to both questions is a qualified "Yes."

Like its parent the citizen's charter ${ }^{6}$ the patient's charters recognise the importance of public services, a welcome change from the past decade. It also emphasises that the NHS belongs to the public, which has a right to know what to expect. Giving patients more power is not stated explicitly, but the charter should help to achieve this.

The charter sets out seven existing rights in the NHS. These may surprise some patients if not health professionals. For example, the charter states the right "to be given a clear explanation of any treatment proposed, including any risks and any alternatives before you decide whether you will agree to the treatment." The Welsh charter goes slightly further, stating that a patient may expect "to help choose care and treatment appropriate to you." After seven existing rights come three new ones, including the right to treatment within two years of joining a waiting list. Missing from the list, however, is any mention of a right to be referred to a consultant or hospital of the patient's or general practitioner's choice.

Another theme running through the charter is the right to information about what health services are available locally $\frac{0}{3}$ and to what standards these will be delivered. Patients will now have the right to have their complaints about NHS services investigated promptly and to receive a written reply $\circ$ from the chief executive or general manager. This emphasis on providing information should be welcomed: poor communication and lack of information are patients' commonest complaints about the NHS.

The charter then goes on to give nine "charter standards," N which are more intentions that rights. Dividing rights from standards like this is understandable: the nature of health care means that governments, regardless of political complexion, are loath to draw up too many rights because of the open $\stackrel{\oplus}{+}$ ended commitment this might entail. In addition, there are 0 problems of definition: perhaps for this reason "respect for privacy, dignity and religious and cultural beliefs" is included as a standard rather than a formal right.

The Labour party has already criticised the standards for their leniency. Some of them-a 30 minute waiting time in $ᄋ$ outpatients, a maximum waiting time for treatment of two years, and a waiting time for an ambulance of 14 minutes (urban area) and 19 minutes (rural area) - are already being bettered in many places. No doubt departmental officials wrestled with setting standards that would bring the poor 